\title{
Rule of Law and Global Governance
}

\author{
Ulrich von Alemann
}

History of the "Rechtsstaat"

The idea of the "Rechtsstaat" is very old. It was a common topic of debate in $19^{\text {th }}$ century Germany. It is linked to statehood and is primarily supposed to control the administrative actions of the state with proper legislation - rule of law versus arbitrary rule of feudal authority. ${ }^{1}$ Especially in Germany the normative doctrine of "Rechtsstaat" is older than the idea of democracy itself; in fact, it is older than the constitutional monarchies in, for example, Great Britain, France, or Scandinavia. In the absolute monarchy of France at the beginning of the $17^{\text {th }}$ century King Louis XIV proclaimed: "L'État, c'est moi!" The Prussian King Frederick II the Great, on the other hand, saw himself as an enlightened monarch and designated himself: "Ich bin der erste Diener des Staates! (I am the first servant of the state!)”

This fits a wide spread story whose validity is questionable but which tells us a lot about the "Rechtsstaat". Frederick the Great, in his castle in Potsdam near Berlin, had been annoyed by the rattling of a mill and had someone inform the miller about this. The miller then answered that "there are still judges in Berlin." The story tells us: even the King of Prussia was subject to law. Until today, this has been a common saying in Germany. At around the same time, the Prussian-German philosopher Immanuel Kant had demanded a law of nations in his 1795 publication "Perpetual Peace: A Philosophical Sketch",

\footnotetext{
${ }^{1}$ Dose (1999).
} 
which was built upon the idea of a "universally peaceful alliance of nations" 2 . The Ideals of Kant stated that all human actions, including the actions of the state, should ultimately be subject to legal principles. Today, in spite of a lot of progress, we are still a long way away from this vision.

But even more than 150 years earlier an international "rule of law" had German roots. This originated in the "Peace of Westphalia" of 1648. It ended the Thirty Years' War between the two Christian denominations, namely Catholic and Protestant. It was the first international congress ever in which all of the big European powers were represented. They arrived at a peace treaty and basically founded the preface to the law of nations in this process. It was a long way and took some 300 years to the "The Hague Conventions" at the end of the $19^{\text {th }}$ century, when a legal containment of war and neutrality were codified. This effort was continued in the League of Nations of 1919 but ultimately failed during the 1930ies. It was not until the foundation of the United Nations in 1945 that a basic ground for international regimes was established. This encompassed not only organizations aimed at security and peace but also organizations concerned with health (WHO), labor (ILO) or culture (UNESCO) and many more.

\section{The Concepts of "Rule of Law", "Law of Nations" and "Global Governance"}

Originally the term "Rechtsstaat" defined a characteristic of the German "Sonderweg (unique path)" in the development of a democratic constitutional state. Rule of law binds every governmental authority to constitution, legislation, and law. The sovereign does not stand above the law. Initially, this was seen in a way that the law was often only perceived formally. It was essential that a law existed, even if the content and goal of this law might have been dubious. This view has since been abolished in Germany after the misuse by National Socialism. The fascists during the 1930s actually presented themselves in part as guarantors of a "Rechtsstaat", which itself passed race laws (Nuremberg laws) that can only be considered violations of human rights. These laws were used to implement inhuman governance. Nowadays, the rule of law is seen everywhere as a concept that enforces natural justice regarding, for example, inalienable human dignity and human rights.

\footnotetext{
${ }^{2}$ Hoeffe (1995).
} 
Authority entails, especially in a democratic rule of law, a monopoly on the use of force. This means that only the state is authorized to use force internally (police, courts, legal system) and externally (military), which has to be subject to judicial examination. The state's monopoly on the use of force can only be justified by the effective comprehension of the constitutions in liberal democracies if the state exercises force lawfully and legitimately. These aspects point to the extraordinary role of the constitutional foundation of democratic authority and the normative expectation towards the state, to continuously gain the acceptance of its subjects. This German concept of "Rechtsstaat" was initially hardly comparable to the English definition of "rule of law". Today, the two concepts have become closer in meaning. In this respect, rule of law is a key to worldwide modern political theory, also in the development and foundation of young democracies.

The general law of nations encompassed all laws that governed the relationships of nations. Initially these nations were seen as international legal personalities that could not suffer any external authority over themselves. Noninterference in the internal politics of each nation was seen as a golden rule of classical diplomacy and law of nations. The world of states was anarchic and only voluntary contractual agreements were acknowledged. During a long historical process, which led to the foundation of the United Nations, this anarchy has been converted into a highly complicated legal framework. Today, we are still in the midst of this process. There is a change from the traditional law of nations to modern international law.

The players of the classical law of nations were the states and their representatives, namely the diplomats. This also changed some time ago. In today's United-Nations' conferences diplomats have been reduced to a minority since representatives of international organizations, corporations, unions, NGOs, scientists etc. make up the majority of delegates. This process has changed government to governance, even global governance and has advanced far. We will come back to this later.

\section{Dimensions of the Rule of Law}

So what is the rule of law? What are its criteria and scale? Can the rule of law be measured? There are an exceedingly large amount of criteria and scales for the rule of law historically and in the present days. We will focus on the pre- 
sent day. To do this I can extract four frameworks from recent publications which indicate definitions of the rule of law.

\section{Table 3: Four Frameworks for the Rule of Law}

\begin{tabular}{|c|c|c|c|c|}
\hline & $\begin{array}{l}\text { World Justice Report } \\
\text { (2010) }\end{array}$ & $\begin{array}{l}\text { Freedom House } \\
(2010)\end{array}$ & $\begin{array}{l}\text { Map of freedom in } \\
\text { the world (2009) }\end{array}$ & $\begin{array}{l}\text { Deficiencies of } \\
\text { rule of law in } \\
\text { failing states } \\
(2011)\end{array}$ \\
\hline 1 & $\begin{array}{l}\text { The government and its } \\
\text { officials and agents are } \\
\text { accountable under law }\end{array}$ & $\begin{array}{l}\text { Independent } \\
\text { judiciary }\end{array}$ & $\begin{array}{l}\text { Is there an independ- } \\
\text { ent judiciary? }\end{array}$ & $\begin{array}{l}\text { No real politi- } \\
\text { cal participa- } \\
\text { tion of the } \\
\text { electorate }\end{array}$ \\
\hline 2 & $\begin{array}{l}\text { The laws are clear, } \\
\text { publicized, stable and } \\
\text { fair, and protect funda- } \\
\text { mental rights, in- } \\
\text { cluding the security of } \\
\text { persons and property }\end{array}$ & $\begin{array}{l}\text { Primacy of rule } \\
\text { of law in civil } \\
\text { and criminal } \\
\text { matters }\end{array}$ & $\begin{array}{l}\text { Does the rule of law } \\
\text { prevail in civil and } \\
\text { criminal matters? } \\
\text { Are police under } \\
\text { direct "civilian } \\
\text { control" }\end{array}$ & $\begin{array}{l}\text { No existence } \\
\text { and guarantee } \\
\text { of human } \\
\text { rights }\end{array}$ \\
\hline 3 & $\begin{array}{l}\text { The process by which } \\
\text { the laws are enacted, } \\
\text { administered and en- } \\
\text { forced is accessible, fair } \\
\text { and efficient }\end{array}$ & $\begin{array}{l}\text { Accountability } \\
\text { of security forces } \\
\text { and military to } \\
\text { civilian authori- } \\
\text { ties }\end{array}$ & $\begin{array}{l}\text { Is there protection } \\
\text { from political terror, } \\
\text { unjustified impris- } \\
\text { onment, exile, or } \\
\text { torture, whether by } \\
\text { groups that support } \\
\text { or oppose the sys- } \\
\text { tem? Is there free- } \\
\text { dom from war and } \\
\text { insurgencies? }\end{array}$ & $\begin{array}{l}\text { No independ- } \\
\text { ence of the } \\
\text { judiciary and } \\
\text { frequent vigi- } \\
\text { lantism }\end{array}$ \\
\hline 4 & $\begin{array}{l}\text { Access to justice is } \\
\text { provided by competent, } \\
\text { independent, and ethi- } \\
\text { cal adjudicators, attor- } \\
\text { neys or representatives, } \\
\text { and judicial officers } \\
\text { who are of sufficient } \\
\text { number, have adequate } \\
\text { resources, and reflect } \\
\text { the makeup of commu- } \\
\text { nities they serve }\end{array}$ & $\begin{array}{l}\text { Protection of } \\
\text { property rights }\end{array}$ & $\begin{array}{l}\text { Do laws, policies, } \\
\text { and practices guaran- } \\
\text { tee equal treatment } \\
\text { of various segments } \\
\text { of the population? }\end{array}$ & $\begin{array}{l}\text { Notorious and } \\
\text { widespread } \\
\text { corruption and } \\
\text { clientelism }\end{array}$ \\
\hline
\end{tabular}

Source: Schulze-Fielitz (2011), 10. 
This already is highly elaborate and does not need any further differentiation. The table points out the diversity of definitions. This is not a deficit, but rather the nature of the issue: There cannot be a universally binding definition of rule of law, for all time periods, regions and issues. Sometimes only a dichotomy exists between a weak rule of law, which especially emphasizes contractual security in international legal relations and a strong version, which particularly includes human rights. In general, the debate about rule of law is a dynamic and continuously differentiating process, which I will discuss in the next part of this text.

\section{Dynamics of the Rule of Law}

The classical old law of nations was applied, as we have seen, from the Peace of Westphalia in 1648 until the Vienna Congress in 1815. The sovereign states were the only players, public agents were non-existent. It was a soft law since no regulating instance stood above the nations. It was an anarchic law in which the strong could usurp the ius ad bellum, the right to war. Since the end of the $19^{\text {th }}$ century, a rapid and dynamic advancement has been taking place from the conventions of The Hague and Geneva to the League of Nations in 1919 up to the United Nations in 1945. And since then advancements have picked up in speed. In light of the general globalization, international jurisdiction has increased exponentially. This has led to an increase in the amount of contracts based on the law of nations by a factor of four. ${ }^{3}$ Nevertheless, this also is connected to an isolation of the source of the law, jurisdiction. In the past, this has always been the nations themselves through internal jurisdiction or externally through inter-country contracts. Nowadays, jurisdiction has become independent of individual nations. International organizations create laws in a way never before witnessed.

"The increasing development of international organizations and international law and its forms of implementation has raised the significance of the law of nations to a new level never before seen in human history. "

\footnotetext{
${ }^{3}$ Schulze-Fielitz (2011), 10.

${ }^{4}$ Schulze-Fielitz (2011), 10.
} 
In this respect, we are witnesses to a new process of international rule of law. Not only has the number of contracts increased but also the number of judicial instances. There is now a "judicalization" of the law of nations which leads to an increase in politically independent international courts and arbitration instances. By now there are supposed to be a total of 125 such instances.

At the moment, a big German research project at Humboldt University Berlin is investigating “The International Rule of Law - Rise or Decline?" The research agenda is as following:

"The Research Group examines the role of international law in a changing global order. Can we, under the current significantly changing conditions, still observe an increasing juridification of international relations based on a universal understanding of values, or are we, to the contrary, rather facing a tendency towards an informalization or a reformalization of international law, or even an erosion of international legal norms? Would it be appropriate to revisit classical elements of international law in order to react to structural changes, which may give rise to a more polycentric or nonpolar world order? Or are we simply observing a slump in the development towards an international rule of law based on a universal understanding of values?'

We can thus come to an intermediary conclusion: The internationalization of law is increasing more and more dynamically with respect to the amount of international contracts and the amount of international dispute settlement institutions. Let us now look at the regional level in Europe.

\section{European Experience of the Rule of Law}

Europe is the world's leading region when it comes to integration and networking of international law. This is the case in two distinct but mutually overlapping institutions: The European Union and the Council of Europe.

The Council of Europe is far less known worldwide and is often confused with the European Union; despite it is a completely independent and selfcontained institution. The Council of Europe was founded on May 5 1949 with the contract of London and today encompasses 47 European nations which represent 820 Million citizens. The Council of Europe is not a state-like structure, like the European Union, but rather a European international organization, a forum for debate and general questions concerning Europe. The

\footnotetext{
${ }^{5}$ http://www.jura.fu-berlin.de/fachbereich/einrichtungen/oeffentliches-recht/lehrende/kriegerh/KFG/index.html, 21.02.2016
} 
Council of Europe far surpasses the core of Europe, the Western- and CentralEuropean area, and encompasses Russia and the former soviet states.

The most important treaty brought forth by the Council of Europe is the European Convention on Human Rights of 1950. This has led to the European Court of Human Rights being its most important institution. Every person in Europe can call upon the European Court of Human Rights and claim that his rights were violated according to the European Convention on Human Rights. Since its reform in 1998 the European Court of Human Rights has grown in influence and has passed multiple judgments that have impacted the legal order of individual nations. These court judgments can in fact not be enforced by any European executive authority, but they have considerable political and lasting effects.

Subject to the rule of law to an even higher degree is the European Union, founded with the Treaties of Rome in 1957, with initially five member nations, but which has continuously expanded and deepened through various treaties. At the moment the Treaty of Lisbon, signed in 2007, is in effect. Since the Treaty of Amsterdam in 1997, the rule of law is an explicitly accentuated foundation of the Union (Art. 6 Abs. 1, now Art. 2 EUV):

"The Union is founded on the values of respect for human dignity, freedom, democra$c y$, equality, the rule of law and respect for human rights, including the rights of persons belonging to minorities. These values are common to the Member States in a society in which pluralism, non-discrimination, tolerance, justice, solidarity and equality between women and men prevail" (Art. 2 EU-Treaty).

The rule of law is also an explicit condition for entry into the EU. Even though the Treaty of Lisbon does not further differentiate the principles of the rule of law, multiple rules of the European Community Law include fundamentals of the rule of law. This is the case in, for example:

- the legality of administration,

- legal principles based on basic rights,

- the right to effective legal protection,

- the right to a fair trial based on the rule of law, public liability for legislative injustice,

- or in the sense of general elementary laws, like the elementary law of commensurability, legal certainty, legitimate expectation, the legal principle that measures should not have retroactive effects, or the prohibition of double jeopardy. 
The ascertainment of all these principles is guarded by the European Court of Justice in Luxembourg, which has grown into a mighty guardian of the European treaties. But more core elements of the rule of law can be identified:

- the existence of basic- and human rights,

- the separation of powers,

- the independence of courts,

- the binding of all state authority in the constitution (Normenhierarchie),

- reservation of the law.

All these principles show a mutual learning process which is aimed at making rule of law a central benchmark in the European constitutional discourse. ${ }^{6}$ In spite of all this general juridification and standardization of the rule of law in Europe, distinct differences in the ways that the rule of law is individually accentuated are evident. Thus different traditions in the rule of law are still continuing to grow, like the British Common Law in contrast to the continental codified law. This difference in the rule of law partly refers to important basic principles, whether a constitutional jurisdiction exists in the nation or not. In Germany the Federal Constitutional Court (Bundesverfassungsgericht) is viewed as the "summit of the rule of law" (Klaus Stern). This is not the case in other countries. All in all, the principle of the rule of law plays a smaller part in European Law in contrast to its paramount importance in the German constitution ("Grundgesetz") and in German law in general.

\section{Global Governance}

The function of the rule of law as a central benchmark for the existence and function of statehood in an international comparison becomes even more heterogeneous than in Europe. Rule of law is not constitutionalized on a global level, not even in the UN-Charter. In addition to that, no international definition or even term for it can be expected in an international linguistic usage. Nevertheless, a "grand coalition" of World Bank, human rights organizations and national and international security experts exists which all "sing the praises of the rule of law together". The UN puts its emphasis on the rule of law particularly on the obligation to the law, separation of powers, effective legal protection through independent courts, and the protection of human rights.

\footnotetext{
${ }^{6}$ Schulze-Fielitz (2011), 3.

${ }^{7}$ Schuppert cited by Schulze-Fielitz (2011), 4.
} 
The current globalization processes imply an increase and compression of cross-border interactions which involve almost all social classes, nations, organizations, group of players, and individuals in a complex system of mutual dependencies. The scope of actions of individuals, the scope of national politics, "Lebenswelten" (lifeworlds), social classification patterns, and deep structures of societies are undergoing lasting changes. ${ }^{8}$ Local, regional, and national global spheres are constantly shrinking and connecting to each other in new ways. The process of globalization poses problems which far surpass classical foreign politics. In addition to that, it poses new requirements for national politics. Thus the development of a global rule of law and an international culture of cooperation is now needed more than ever.

The idea of rule of law is one of the great achievements of modern democracies. Global governance is only possible with a strong global rule of law. The long-term stability of global societies, democracy, freedom, and solidarity can only be sustained through a cooperation-encouraging set of rules, in other words, institutional and legal containment of power is needed. The formation of global rules has to incorporate the differing effects of globalization and combine them with generally accepted principles, norms, and rules with special provisions for specific groups of nations. The founders of the UN already pursued the goal of a worldwide rule of law but could only achieve it in incipient stages. For example they created the International Court of Justice in The Hague in 1945. However, nations could decide if they wanted to adhere to the court's rulings (Germany declared its submission in 2008). In 2002 the International Criminal Court was also established in The Hague. It has, however, not been recognized by some nations to this day (e.g. USA, China, India, Russia, Israel and Turkey). Vietnam, however, has joined.

\section{Conclusion: Cultural Diversities of the Rule of Law?}

Today, the rule of law has become a dynamic process which far surpasses the UN Charter and the UN-sub-organizations. For instance, it encompasses maritime law, diplomatic- and consulate law, space law, and trade law (WTO). Initially, the law of nations was only applied between sovereign nations. To-

\footnotetext{
${ }^{8}$ Messner/Gu/Humphrey (2008).
} 
day, multiple networks of interconnected agents exist: Diplomats of nations, international organizations, corporations and civil society. This new situation is called "global governance". However, this process also experiences a lot of set-backs, contradictions, and inconsistencies. It is evident regularly in regional and global conflicts, even today. Thus, enforcement of international rule of law still constitutes a big challenge.

There are two understandings of the rule of law which vary in sophistication: Weaker doctrines (weak law: without connections to notions of democracy and justice, more commonly accepted in international law) and stronger doctrines (strong law: e.g. validity of human rights, more commonly accepted in the western hemisphere). The ASEAN-States have incorporated a strengthening of the rule of law since 20.11.2007 onwards (ASEAN-Charter). In Islamic constitutions the concept of rule of law has not prevailed and is sometimes even rejected completely. Most nations, however, are convinced that democracy cannot exist without the rule of law, but that the rule of law can exist without democracy. It is disputed whether the basis of the rule of a constitutional democracy has to be a market-based system with decentralized policymakers. But surely it is true that a market-based economy cannot exist without a fundamental rule of law, especially with regards to the freedom of contract and law of contract.

Finally, we can sum up by saying that the increasing development of international organizations and of international law and its forms of implementation has elevated the meaning of the law of nations to a level never seen before in human history. The juridification in the process of globalization, however, is subject to a multitude of set-backs, contradictions, and inconsistencies. There is a dramatic increase in juridification but no standardization.

Many questions thus remain unanswered: Do all involved nations understand the juridified rules in the same way? Does a hegemonic claim of European judicial values through the suppression of deviating traditions exist? In how far is legal thinking dependent on culture? Is there another rule of law, apart from the one coined by western culture? These are all questions that are still open and should be discussed further in a global forum. 


\section{References}

Dose, Nicolai (1999): Der deutsche Rechtsstaat. In: Ellwein, Thomas/ Holtmann, Everhard (eds.): 50 Jahre Bundesrepublik Deutschland. Sonderheft der Politischen Vierteljahresschrift Vol. 30. Opladen. 118-134.

Hoeffe, Otfried (ed.) (1995): Immanuel Kant. Zum ewigen Frieden. Berlin.

http://www.jura.fu-berlin.de/fachbereich/einrichtungen/oeffentlichesrecht/lehrende/kriegerh/KFG/index.html, 21.02.2016

Messner, Dirk/Jing Gu/Humphrey, John (2008): Global Governance and Developing Countries. The Implications of the Rise of China. In: World Development, Vol. 36. 274-292.

Schulze-Fielitz, Helmuth (2011): Zur Geltung des Rechtsstaates: Zwischen Kulturangemessenheit und universellem Anspruch. In: Zeitschrift für Vergleichende Politikwissenschaft 2011. 1-23. 
